\title{
Emboli Air Ketuban
}

\author{
Ratih Kumala Fajar Apsari', Bambang Suryono ${ }^{2}$ \\ Fellow Anestesi Obstetri Anestesiologi dan Terapi Intensif FK UGM - RSUP Dr. Sardjito ${ }^{1}$ \\ Konsultan Anestesi Anestesi Obstetri Departemen Anestesiologi dan Terapi Intensif FK UGM / \\ RSUP Dr. Sardjito Yogyakarta ${ }^{2}$
}

\begin{abstract}
Abstrak
Emboli cairan amnion (EAK) adalah komplikasi kehamilan yang jarang namun membawa angka mortalitas yang tinggi. Patogenesis yang tepat dari kondisi ini masih belum diketahui. Emboli air ketuban (EAK) atau amniotic fluid embolism (AFE) atau anaphylactoid syndrome of pregnancy adalah salah satu komplikasi kehamilan yang paling membahayakan. Cairan ketuban, debris fetal diduga menyebabkan kolaps kardiovaskular dengan cara memicu reaksi imun/anafilaktoid maternal. Patofisiologi EAK hingga kini masih belum jelas tetapi diduga melibatkan kaskade immunologis. Kematian maternal bisa terjadi karena cardiac arrest mendadak, perdarahan karena koagulopati, dan kegagalan organ multipel dengan acute respiratory distess syndrome (ARDS). Gejala dan tanda EAK antara lain dispnea akut, batuk, hipotensi, sianosis, bradikardia fetal, ensefalopati, hipertensi pulmoner akut, koagulopati, dan sebagainya. Diagnosis EAK adalah bersifat klinis dan ditegakkan setelah menyingkirkan kemungkinan penyebab lain. Penatalaksanaan bersifat suportif dan memerlukan persalinan janin jika diperlukan, support respiratorik, dan support hemodinamik. Prognosis maternal setelah EAK masih sangat buruk meski tingkat survival janin sekitar 70\%. Pasien dengan EAK paling baik dikelola di unit perawatan kritis oleh tim multidisiplin dan dengan manajemen supportif.
\end{abstract}

Kata kunci: amniotik; emboli; cairan; kehamilan; komplikasi

\section{Amniotic Fluid Embolism}

\begin{abstract}
Amniotic fluid embolism (AFE) is a rare complication of pregnancy carrying a high mortality rate. The exact pathogenesis of the condition is still not known. Amniotic fluid embolism (AFE) or anaphylactoid syndrome of pregnancy is one of the most dangerous pregnancy complications. Amniotic fluid, fetal debris is thought to cause cardiovascular collapse by triggering a maternal immune / maternal anaphylactoid reaction. The pathophysiology of AFE remains unclear but is thought to involve an immunological cascade. Maternal deaths may occur due to sudden cardiac arrest, bleeding due to coagulopathy, and multiple organ failure with ARDS. AFE symptoms and signs include acute dyspnea, cough, hypotension, cyanosis, fetal bradycardia, encephalopathy, acute pulmonary hypertension, coagulopathy. Management is supportive, respiratory support, and haemodynamic support. The maternal prognosis is very poor even though the survival rate of the fetus is about $70 \%$. Patients with AFE are best managed in a critical care unit by a multidisciplinary team and management is largely supportive
\end{abstract}

Key words: amniotic; complication; embolism; fluid; pregnancy 


\section{Pendahuluan}

Emboli air ketuban (EAK) atau amniotic fluid embolism (AFE) atau anaphylactoid syndrome of pregnancy adalah salah satu komplikasi kehamilan yang paling membahayakan, dimana dipostulasikan bahwa cairan amnion, sel janin, rambut, atau debris lainnya masuk ke dalam sirkulasi pulmoner maternal, menyebabkan kolaps kardiovaskular. EAK pertama kali dilaporkan oleh Meyer pada tahun 1926, dan sindroma ini pertama kali dijelaskan oleh Steiner dan Lushbaugh pada tahun $1941 .{ }^{1}$ Meski demikian, kondisi ini sangat jarang terjadi dan patofisiologi pastinya masih belum diketahui. ${ }^{2}$ Beberapa temuan baru dari penelitian menemukan biomarker baru yang dapat membantu dalam memprediksi dan mendiagnosis AFE. Pemahaman tentang patogenesis EAK telah mengalami peningkatan drastis dalam dua dekade terakhir sejak kelainan ini diketahui sebagai penyebab utama nomor satu kematian maternal di Amerika Serikat. Akan tetapi, bukti untuk EAK berasal terutama dari laporan kasus, kasus serial otopsi, atau kasus serial tanpa kontrol karena kondisi ini jarang terjadi. Selain itu, beberapa aspek dari kondisi ini masih menjadi topik kontroversi. ${ }^{3}$

\section{Epidemiologi}

Insidensi emboli air ketuban sulit untuk ditentukan karena (1) EAK adalah diagnosis eksklusi, (2) tidak ada definisi yang diterima secara seragam untuk identifikasi kasus EAK, dan (3) perbedaan metode penegakan diagnosis. ${ }^{4}$ Insidensi EAK diperkirakan terjadi antara 1 dari 8000 dan 1 dari 80000 persalinan. Insidensi pastinya masih belum diketahui karena diagnosis yang tidak akurat dan pelaporan yang tidak konsisten untuk kasus nonfatal. Sindroma ini biasanya terjadi selama persalinan, segera setelah persalinan per vagina atau saesar, atau selama dilatasi trimester kedua dan prosedur evakuasi. Penelitian-penelitian sebelumnya menemukan tingkat mortalitas yang mencapai $61-86 \%$, tetapi estimasi terbaru menunjukkan fatalitas kasus sebesar 13-26\%. Penurunan dalam risiko untuk mortalitas maternal karena EAK ini mungkin dikarenakan diagnosis dini dan perawatan resusitasi yang lebih baik serta perubahan dalam kriteria inklusi kasus. Outcome untuk janin masih buruk jika EAK terjadi sebelum persalinan, dengan tingkat mortalitas neonatal lebih dari $10 \%{ }^{1}$

Rasio mortalitas maternal yang terkait dengan EAK berkisar dari 0,5-1,7 kematian per 100.000 kelahiran hidup atau persalinan $(0,5$ di Swedia dan Inggris, 0,7 di Kanada, 1,5 di Australia, dan 1,0-1,7 di Amerika Serikat). Di negara berkembang, laporan rasio mortalitas maternal antara $1,8-5,9$ per 100.000 persalinan. Tingkat mortalitas maternal berdasarkan data literatur pada tahun 1979 adalah sebesar $86 \%$, angka ini turun menjadi 61\% antara periode 1988-1994. Penelitian berbasis populasi terbaru melaporkan penurunan dalam tingkat mortalitas kasus karena EAK $(13,3 \%$ di Kanada, $21,6 \%$ di Amerika Serikat, $24,0 \%$ di Inggris, dan 44,0\% di Swedia), menunjukkan bahwa EAK bukanlah kelainan yang selalu berakhir dengan kematian. Penurunan tingkat mortalitas ini mungkin disebabkan perbaikan dalam pelaporan, inkonsistensi dalam definisi kasus, atau perbaikan dalam treatment. Sebuah kemungkinan lain adalah adanya bias publikasi dalam penelitian-penelitian awal, karena pelaporan selektif terhadap kasus berat. Tingkat mortalitas perinatal karena EAK fatal dalam dekade terakhir berkisar antara 9 dan $44 \%{ }^{3}$ World Health Organization mendefinisikan kematian ibu sebagai kematian seorang wanita selama kehamilan atau dalam 42 hari setelah kehamilan karena penyebab yang terkait dengan kehamilan atau diperparah olehnya. Kematian ibu dapat dibagi menjadi langsung atau tidak langsung berdasarkan etiologinya. Kematian langsung adalah akibat dari komplikasi kebidanan dari keadaan hamil (contoh: Preeklampsia), sementara kematian tidak langsung adalah karena penyakit terkait yang dapat diperburuk oleh efek fisiologis kehamilan (contoh: penyakit jantung yang sudah ada sebelumnya). EAK adalah salah satu dari lima penyebab utama kematian obstetrik langsung di negara maju. Angka kematian karena EAK di Inggris adalah 0,33 / 100.000 (2010-2012). Ini adalah penyebab utama kelima kematian obstetrik langsung di Inggris setelah tromboemboli, sepsis, perdarahan, dan preeklamsia / eklampsia. ${ }^{4}$ 


\section{Faktor Risiko}

Emboli cairan ketuban dianggap sebagai kejadian yang tidak bisa diprediksi dan tidak bisa dicegah dengan penyebab yang tidak diketahui. EAK dapat terjadi pada ibu sehat selama persalinan, selama seksio sesarea, setelah persalinan per vagina abnormal, atau selama trimester kedua kehamilan EAK juga dapat terjadi hingga 48 jam pasca persalinan. EAK juga dapat terjadi selama aborsi, setelah trauma abdomen, dan selama amnioinfusi. EAK juga telah dilaporkan terjadi setelah injeksi intrauteri dengan saline hipertonik untuk memicu aborsi. ${ }^{1}$ Berdasarkan penelitian yang meninjau kasus EAK dalam database register UKOSS (UK Obstetric Surveillance System), faktor-faktor risiko yang terkait dengan kejadian EAK adalah usia ibu di atas 35 tahun, induksi persalinan, kehamilan multipel, dan persalinan sesar. Beberapa penelitian observasional menunjukkan bahwa ibu yang membawa janin laki-laki memiliki risiko lebih tinggi untuk EAK. Ini mungkin memperkuat dugaan yang hampir sama bahwa inkompatibilitas rhesus atau ABO mungkin adalah salah satu faktor dalam kemunculan EAK. ${ }^{5}$ Banyak faktor risiko telah dikaitkan dengan EAK, tetapi kausalitas belum terbukti untuk sebagian besar dari mereka meskipun hubungan yang konsisten telah diamati dengan usia ibu yang lebih tua dan

Tabel 1. Faktor Resiko yang Berhubungan dengan Emboli Air Ketuban

\begin{tabular}{l}
\hline Usia $>35$ tahun \\
Multiparitas \\
Janin laki-laki \\
Induksi persalinan \\
Penggunaan alat bantu untuk persalinan \\
Seksio sesaria \\
Trauma cervix \\
Hiperstimulasi uterus \\
Preeklamsia \\
Eklamsia \\
Plasenta previa \\
Solusio plasenta \\
Etnik minoritas
\end{tabular}

induksi persalinan medis. Risiko yang terkait disebutkan dalam Tabel 1. Penggunaan alat bantu, persalinan sesar, trauma serviks atau ruptur uterus merupakan upaya untuk melahirkan janin setelah terjadi EAK. Beberapa penulis berpendapat bahwa rangsangan uterus adalah waktu yang paling mungkin cairan ketuban untuk bersentuhan dengan sirkulasi ibu, sehingga mempertanyakan peran kausatif stimulasi uterus. Dengan demikian, tidak ada faktor risiko yang signifikan yang dapat dibuktikan saat ini. Risiko kekambuhan kondisi ini juga tidak diketahui, meskipun ada beberapa laporan tentang kehamilan berikutnya yang berhasil. ${ }^{4}$

\section{Patogenesis}

Paparan sirkulasi ibu ke cairan ketuban atau antigen janin secara universal diterima sebagai prasyarat untuk terjadinya EAK. Hal ini dapat terjadi melalui lokasi trauma uterus, vena endoserviks, atau tempat perlekatan plasenta. Trauma uterus minor terjadi pada saat persalinan normal atau dengan alat bantu atau seksio. Mekanisme pasti yang mendasari terjadinya EAK setelah pemaparan ini masih belum diketahui. Secara historis, EAK dianggap disebabkan oleh obstruksi mekanik pembuluh darah paru oleh embolus cairan ketuban yang terdiri dari sel skuamosa, vernix caseosa, rambut lanugo, trofoblas, mucin, dan mekonium. Tetapi ini tidak bisa menjelaskan seluruh manifestasi klinis dari sindroma tersebut. ${ }^{4}$

Kemunculan air ketuban dan materi fetoplasental telah terbukti sering ditemukan di dalam sirkulasi ibu hamil sehat tanpa menyebabkan gangguan. Dengan demikian, kemunculan air ketuban di dalam sirkulasi sebagai satu-satunya penyebab morbiditas atau mortalitas menjadi diragukan. Perhatian kini dialihkan ke kaskade immunologis yang terkait, yang kini telah diterima sebagai penyebab mendasar sekuele patofisiologis dan gambaran klinis EAK. EAK diperkirakan berasal dari mekanisme yang dimediasi imunitas, mengingat kesamaannya dengan syok septik atau syok anafilaksis. Ini hasil dari respon imunologi abnormal ibu setelah paparan antigen janin yang mengarah ke pelepasan berbagai mediator pro- 
inflamasi. Kini telah diajukan sebutan lain untuk EAK yang lebih akurat yaitu 'anaphylactoid syndrome of pregnancy'. ${ }^{5}$ Kemunculan EAK memerlukan dua syarat, yaitu masuknya komponen janin ke dalam sirkulasi maternal, dan emboli pulmoner atau reaksi imun/anafilaktoid maternal yang signifikan terhadap cairan amniotik atau komponen janin. ${ }^{6}$

Mekanisme imunologi yang tepat masih belum diketahui. Cairan ketuban itu sendiri mengandung berbagai zat vasoaktif dan prothrombotik seperti faktor pengaktif platelet, interleukin 1 (IL-1), Tumor Necrosis Factor-alpha (TNF $\alpha$ ), leukotrien C4 dan D4, endotelin, faktor jaringan, asam arakidonat, dan lainnya yang ketika dilepaskan ke dalam cairan. sirkulasi darah dapat menyebabkan vasokonstriksi, bronkokonstriksi, dan koagulasi. Mekanisme anafilaktik didukung oleh penelitian yang menunjukkan peningkatan degranulasi sel mast dan disanggah oleh penelitian yang gagal menunjukkan peningkatan serum tryptase. Aktivasi komplemen sebagai mekanisme utama telah diusulkan. Tingkat faktor pelengkap C3 dan $\mathrm{C} 4$ telah ditemukan berkurang pada pasien dengan EAK. Selanjutnya, sel mast dapat diaktifkan secara sekunder setelah aktivasi komplemen. Agregasi trombosit dan aktivasi neutrofil juga mekanisme lain yang diusulkan untuk melepaskan mediator inflamasi yang pada akhirnya mengarah pada sindroma klinis. Alasan untuk aktivasi kaskade koagulasi tidak sepenuhnya dipahami. Faktor jaringan dalam cairan ketuban dan sel amniotik apoptosis dapat memulai kaskade koagulasi, tetapi masih diragukan jika sejumlah kecil faktorfaktor ini dapat mengarah pada gambar koagulasi intravaskular diseminata (DIC) yang terlihat pada EAK.

Clark $^{7}$ mengusulkan sebuah model bifasik untuk konsekuensi hemodinamik EAK. Respon awal adalah hipertensi pulmoner akut dan vasospasme yang berakibat pada gagal ventrikel kanan, hipoksia, dan cardiac arrest. Jika pasien mampu melewati fase awal ini, hipertensi pulmoner biasanya tidak bisa bertahan dan bisa tergantikan oleh kegagalan ventrikel kiri dan edema pulmoner. Hankins et $\mathrm{al}^{8}$ menunjukkan dengan model binatang bahwa injeksi $2,5 \mathrm{ml} /$ $\mathrm{kg}$ cairan amniotik homolog IC meningkatkan resistensi jantung kanan dan vaskular sistemik. Mereka juga menunjukkan bahwa kemunculan mekonium diperlukan untuk menghasilkan gagal jantung kiri dan hipoksia. ${ }^{9}$

\section{Patofisiologi}

Teori awal tentang EAK mempostulasikan bahwa emboli fisik multipel dari material fetoplasental berakibat langsung pada kolaps kardiorespiratorik. Berbagai penelitian binatang dan biokimia gagal membuktikan teori ini, sehingga memperkuat dugaan bahwa mekanisme kerja utama dalam EAK adalah akibat dari aktivasi abnormal sejumlah marker inflamatorik

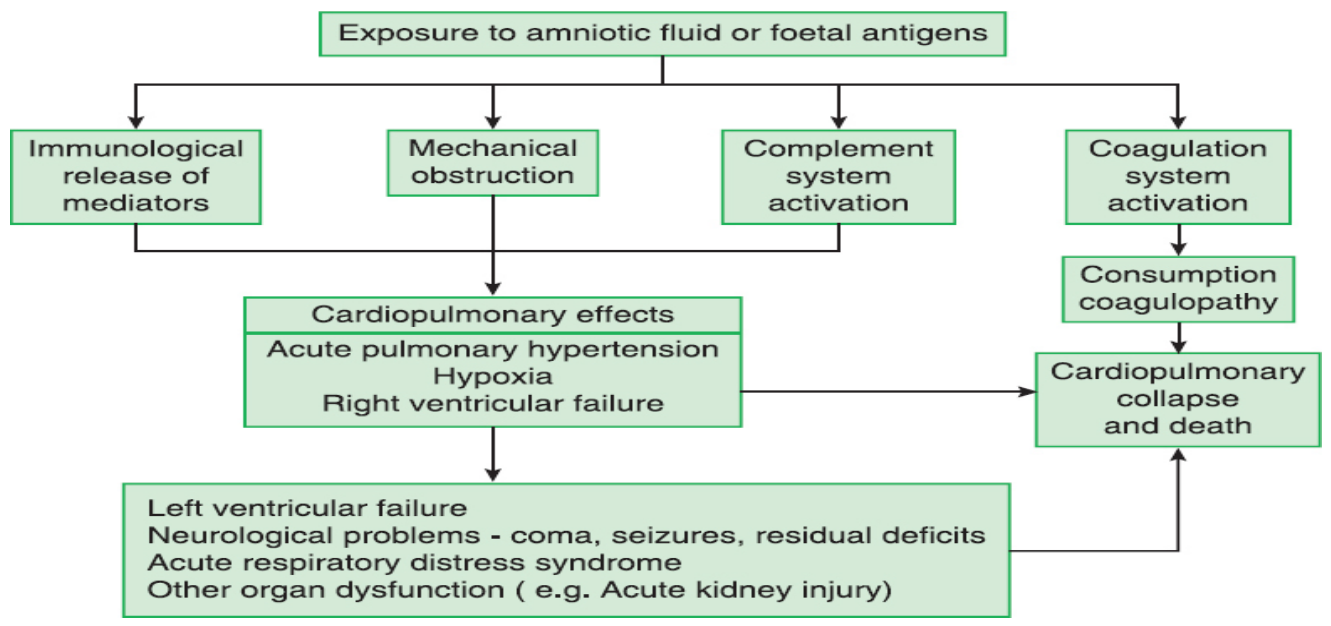

Gambar 1: Patofisiologi emboli air ketuban

Dikutip dari: Girendra Sodera, 2015 
dan kaskade pembekuan darah. Beberapa mekanisme fisik telah diduga sebagai pemicu, yang mencakup kontraksi abnormal, robekan serviks, atau keterlibatan abruptio plasenta. Akan tetapi, tidak ada dari semua ini yang terbukti. Kemunculan air ketuban dan material janin di dalam arteri uteri ibu yang menjalani prosedur obstetrik rutin seperti persalinan sesar, tanpa ada tanda-tanda EAK, menunjukkan kemungkinan adanya mekanisme yang masih belum diketahui. ${ }^{5}$ Penyebab reaksi dalam EAK dicoba untuk dijelaskan oleh dua hipotesis: efek cairan amniotik sendiri atau keanehan dari host (reaksi hipersensitivitas).

Reaksi respiratorik awal kemungkinan dimulai dengan vasospasme pulmoner. Vasospasme bisa disebabkan karena mikroemboli amniotik yang memicu pelepasan metabolit arachidonic acid dan menyebabkan hipertensi pulmoner, shunting intrapulmoner, bronkospasme, dan hipoksia berat. Manifestasi kedua mencakup inotropisme negatif dan kegagalan ventrikel kiri yang menyebabkan peningkatan edema paru dan hipotensi yang dengan cepat mengakibatkan syok. Manifestasi ketiga adalah respon neurologis terhadap jejas respiratorik dan hemodinamik, yang bisa mencakup kejang, confusion, atau koma. ${ }^{1}$ Kolaps sirkulatorik singkat, pergeseran cairan keluar dari ruang intravaskular, dan onset koagulopati konsumtif dan komplikasi jantung dan paru yang terjadi selanjutnya merupakan ciri khas EAK. Mekanisme yang mendasari ini diduga merupakan respon terhadap air ketuban atau komponen selular trofoblastik yang diperantarai imun. Sejumlah eksperimen in vitro memberikan bukti adanya respon koagulan dan humoral. Mediator seperti prostaglandin, serotonin, enzim proteolitik, leukotriene, tryptase, dan histamine telah diketahui terlibat. Tinjauan tentang patogenesis EAK ditunjukkan pada Gambar 1.4

\section{Koagulasi}

Air ketuban mengaktifkan komplemen dalam kondisi tertentu dan menyebabkan sel terpapar dengan komplemen prokoagulan seperti phosphatidylserine dan tissue factor. Surfaktan janin dengan struktur mirip thromboplastin dan memiliki efek tromboplastik, meningkat jumlahnya di dalam air ketuban menjelang kelahiran. Cysteine protease, ditemukan dalam air ketuban dan amniochorion, dapat mengaktifkan faktor $\mathrm{X}$ secara in vitro. Trombosit juga mengalami agregasi yang irreversibel di dalam air ketuban dan melepaskan faktor trombosit III. Air ketuban sendiri berisi faktor II, VII, dan X yang teraktivasi. Stimuli terhadap kaskade pembekuan darah di sejumlah titik ini dapat memicu terjadinya DIC dan kemudian koagulopati. Selain itu, air ketuban diketahui memiliki antikoagulan dalam konsentrasi tinggi seperti thrombomodulin, annexin $\mathrm{V}$, dan tissue factor pathway inhibitor-2. Korelasi antara kemampuan air ketuban untuk memperpendek waktu re-kalsifikasi plasma dan konsentrasi surfaktan air ketuban telah ditemukan. Meski demikian, beberapa pasien dalam register EAK atau serial kasus tidak menunjukkan adanya koagulopati, meski diduga memiliki EAK. Ini menggarisbawahi apakah kesulitan dalam diagnosis akhir, atau variasi dalam penyakit, yang mendasari temuan yang inkonsisten dalam penelitian binatang. Salah satu kemungkinan penjelasan untuk ini adalah bahwa pasien tanpa gambaran koagulopati cenderung meninggal, meski setelah upaya resusitasi, dalam fase awal penyakit. DIC mungkin tidak sempat untuk muncul pada pasien ini. Akan tetapi, ketika merawat pasien dengan suspek klinis EAK, harus diasumsikan bahwa koagulopati konsumtif sangat mungkin terjadi dan bisa terjadi pada awal perjalanan penyakit. $^{5}$

\section{Humoral}

Senyawa biokimia aktif lainnya yang ditemukan dalam kadar tinggi di dalam air ketuban adalah endothelin, sebuah vasokonstriktor kuat yang juga menurunkan kontraktilitas miokardial, mungkin menjelaskan penurunan dalam fungsi jantung yang tampak dalam kasus EAK dan penelitian pada binatang, sejumlah marker inflamatorik seperti sitokin, leukotrine, dan prostaglandin juga telah diketahui keterlibatannya. Mediator humoral berperan penting dalam patologi EAK, seperti halnya dalam sepsis dan bentuk syok distributif lainnya. Produksi senyawa-senyawa ini oleh unit fetoplasental mungkin bertujuan 
untuk melindungi dari episode perdarahan fetomaternal dan mungkin berperan penting dalam keberlangsungan kehamilan. ${ }^{5}$

\section{Hemodinamik}

Akibat dari faktor humoral tersebut, kerusakan hemodinamik awal kemungkinan disebabkan karena vasospasme pulmoner, hipertensi pulmoner, dan disfungsi ventrikel kanan yang pada akhirnya menghasilkan hipoksia. Dalam sebuah laporan kasus ditemukan gagal ventrikel kanan akut dengan right to left septal bulging. Embolisasi fisik mikrovaskularisasi pulmoner oleh material fetoplasental mungkin berkontribusi terhadap gambaran klinis ini. Ini mungkin bersifat sementara, tetapi dapat menyebabkan primary lung injury dan acute respiratory distress syndrome (ARDS). Bukti awal menunjukkan bahwa hipertensi pulmoner adalah gambaran yang menonjol dari kondisi ini, sehingga memerlukan terapi dengan vasodilator pulmoner. Penelitian berikutnya, yang menggunakan monitoring invasif selama fase akut penyakit, menunjukkan periode awal hipertensi pulmoner, yang diikuti dengan kegagalan ventrikel kiri karena gangguan fungsi ventrikel kiri. Kegagalan ventrikel kanan awal yang diikuti kegagalan ventrikel kiri

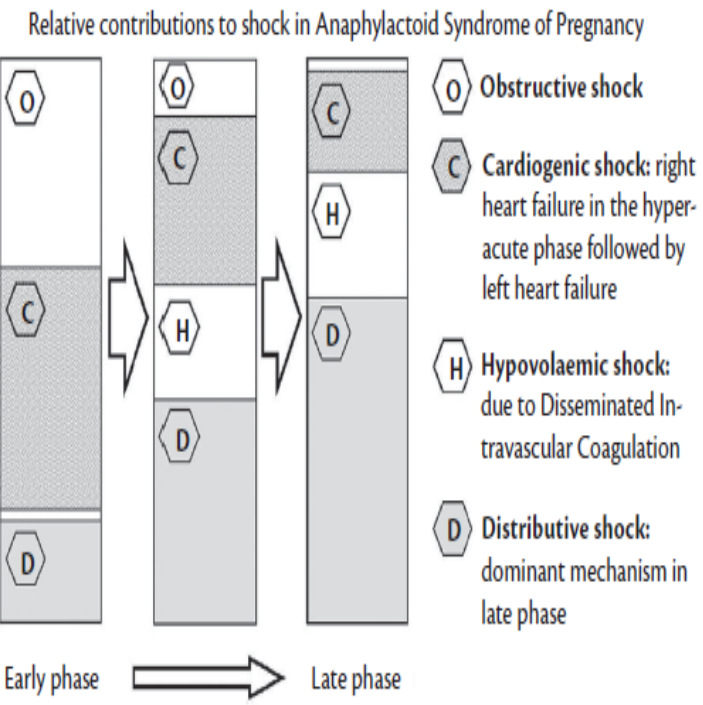

Gambar 2. Dugaan kontribusi tipe-tipe syok dalam EAK dengan respon bifasik

Dikutip dari: Anderson JA, 2016 memunculkan dugaan bahwa EAK adalah sebuah penyakit bifasik. Seiring penurunan dalam preload sisi kiri menyebabkan gagal ventrikel kiri dan hipotensi sistemik, ini memperberat syok kardiogenik dengan mengurangi perfusi miokardial (gambar 2). ${ }^{5}$ Gambar 2. Dugaan kontribusi tipe-tipe syok dalam EAK dengan respon bifasik. ${ }^{5}$ Berkurangnya cardiac output dan hipoksia maternal akan mengakibatkan berkurangnya ketersediaan oksigen bagi janin. Selain itu, kontraksi rahim fisiologis yang normal akan memotong secara sementara aliran darah rahim selama persalinan. Akan tetapi, aliran darah berlanjut kembali selama relaksasi rahim. Pelepasan catecholamine ke dalam sirkulasi maternal selama fase akut EAK diduga memicu pola kontraksi tetanik. Kedua faktor ini mungkin menyebabkan terjadinya fetal distress. ${ }^{5}$

\section{Gambaran Klinis}

Manifestasi awal dari emboli air ketuban adalah distress respiratorik, diikuti oleh gangguan hemodinamik jika terjadi edema pulmoner dan syok. Temuan ini mungkin diikuti oleh hipoperfusi serebral dengan manifestasi klinis kejang, confusion, dan koma. Kematian maternal bisa terjadi karena cardiac arrest mendadak, perdarahan karena koagulopati, dan kegagalan organ multipel dengan ARDS. ${ }^{10}$ Sindroma EAK biasanya terjadi selama persalinan, tetapi bisa terjadi hingga 48 jam postpartum. EAK tipikal bisa dibagi menjadi tiga fase. Pada fase awal, terjadi hipertensi pulmoner dan sistemik yang bersifat sementara. Fase ini biasanya terjadi dalam 30 menit pertama dan menyebabkan hipoksemia karena ventilation perfusion mismatch. Pada fase ini juga bisa terjadi kerusakan miokardial, yang semakin diperberat oleh mediator yang terkait dengan EAK. Mortalitas sangat tinggi selama fase akut EAK ini. Fase kedua ditandai dengan depresi fungsi ventrikel kiri dengan normalisasi tekanan arterial pulmoner. Depresi miokardial dan hipoksia muncul akibat jejas pulmoner dan/ atau cardiac arrest. Fase akhir ditandai oleh gagal jantung, acute respiratory distress, dan koagulopati. Ada tiga subtipe EAK, yaitu klasik, anafilaktoid, dan DIC. Subtipe klasik ditemukan respiratory arrest atau distress, sedangkan 
cardiac arrest atau disfungsi ventrikel ditemukan terutama dalam subtipe anafilaktoid, dan perdarahan masif ditemukan dalam subtipe DIC. ${ }^{2}$ Dispnea akut atau mendadak, agitasi, menggigil, berkeringat, batuk, dan cemas adalah gejala premonitorik yang sering ditemukan. Sulit bernapas dan takipnea mungkin bisa terjadi. Berikut ini adalah gejala dan tanda yang sering ditemukan pada pasien EAK: ${ }^{1}$

- Batuk, biasanya adalah manifestasi dari dispnea

- Perubahan status mental

- Penurunan drastis dalam nilai pulse oximetry atau penurunan atau hilang mendadak ETCO

- Hipotensi. Gangguan hemodinamik terjadi cepat setelah tanda prodromal ini. Hipotensi adalah tanda dan gejala yang paling sering muncul (100\%).

- Sianosis. Ventilation-perfusion mismatch karena konstriksi vaskular pulmoner saat onset EAK mungkin memicu hipoksia mendadak dan henti pernapasan. Seiring memburuknya hipoksia/hipoksemia, sianosis sirkumoral dan perifer dan perubahan dalam membran mukosa bisa terjadi.

- Bradikardia janin. Terjadi sebagai respon terhadap kerusakan hipoksik. Denyut jantung $60 \mathrm{x} /$ menit atau kurang selama 3-5 menit mungkin mengindikasikan bradikardia terminal.

- Ensefalopati, diduga disebabkan karena hipoksia dan bisa ditandai perubahan status mental hingga kejang. Kejang tonik-klonik ditemukan pada $10-50 \%$ pasien.

- Atoni uteri, biasanya menyebabkan perdarahan berlebihan setelah persalinan.

- Vasospasme dan hipertensi pulmoner akut menyebabkan gagal ventrikel kanan, hipoksia, dan henti jantung. Jika pasien selamat dari jejas awal ini, selanjutnya hipertensi pulmoner biasanya tidak menetap dan mungkin digantikan oleh gagal ventrikel kiri dan edema pulmoner.

- Koagulopati atau perdarahan berat. Kelainan koagulasi adalah tanda yang menonjol dari sindroma air ketuban. DIC ditemukan pada lebih dari $83 \%$ pasien dengan EAK. Onset bisa terjadi dalam 10-30 menit sejak onset gejala atau mungkin terlambat hingga 4 jam. Apakah koagulopati adalah proses konsumtif atau karena fibrinolisis masih masih menjadi kontroversi. Cairan ketuban berisi tissue factor yang berperan sebagai prokoagulan dan mungkin bertanggung jawab atas koagulopati. Atau, koagulopati mungkin terkait dengan fibrinolisis karena peningkatan kadar plasminogen activation inhibitor-1 dalam air ketuban.

Jika janin masih in utero selama onset awal EAK, abnormalitas denyut jantung janin hampir selalu ditemukan. Deselerasi akut berkepanjangan atau deselerasi akhir mungkin mengindikasikan adanya hipoksia fetal dan penurunan aliran darah uteri karena shunting darah maternal ke sirkulasi sentral. ${ }^{11}$ Sebuah penelitian tentang kematian maternal menemukan bahwa 11 dari 17 pasien yang mengakami EAK melaporkan beberapa atau semua gejala berikut: breathlessness, nyeri dada, merasa kedinginan, lightheadedness, distress, panik, merasakan sensasi tertusuk jarum di jari, mual, dan muntah. Interval antara onset gejala dan kolaps bervariasi (dari hampir sesaat hingga 4 jam setelahnya). Gejala-gejala ini mungkin mengindikasikan hipoksia dan mungkin memberikan petunjuk pertama terhadap diagnosis emboli air ketuban yang sedang berlangsung sebelum terjadinya kolaps dan perdarahan. Monitoring oksigenasi maternal menggunakan pulse oximetry pada pasien ini seharusnya dipertimbangkan dalam periode peripartum untuk mendeteksi sejak dini pasien yang mungkin nantinyab mengalami EAK. ${ }^{3}$ Kasus EAK telah dilaporkan terjadi sebelum persalinan, selama dan setelah persalinan normal, setelah persalinan dengan instrumen, dan setelah persalinan sesar. EAK juga dapat terjadi selama evakuasi uteri dan amniocentesis, tetapi lebih jarang. ${ }^{5}$

\section{Diagnosis}

Hingga saat ini, salah satu cara penegakan diagnosis EAK adalah secara klinis berupa hipotensi akut atau cardiac arrest, hipoksia akut, atau koagulopati tanpa ada kemungkinan penyebab lain yang menjelaskan gejala dan tanda yang muncul. Diagnosis klinis ini pada dasarnya adalah diagnosis eksklusi berdasarkan 


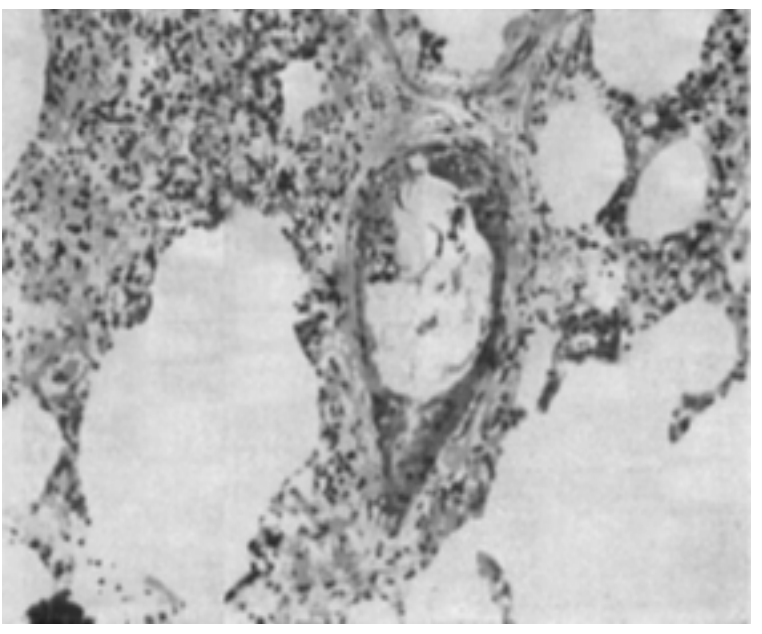

Gambar 3. Arteri kecil di dalam paru menunjukkan gambaran bagian tengah pembuluh darah yang diblokir oleh embolisme sel skuamosa (skuamosa epitelial dan vernix caseosa). ${ }^{12}$

gambaran klinis yang menyerupai embolisme dan anafilaksis. Satu cara diagnosis lainnya adalah berdasarkan deteksi sel skuamosa fetal di dalam sirkulasi pulmoner ibu berdasarkan pemeriksaan patologi. ${ }^{6}$ Diagnosis dengan deteksi patologis komponen janin di dalam sirkulasi maternal masih sangat terbatas dan kontroversial. Karena sel fetal bisa ditemukan pada 21 hingga 100\% ibu hamil tanpa EAK, kemunculan sel janin di dalam pembuluh darah pulmoner bukanlah kriteria diagnostik yag meyakinkan untuk EAK. Sel skuamosa atau trophoblastik bisa ditemukan secara normal dalam sirkulasi pulmoner ibu selama periode peripartum dari pasien dengan pregnancy-induced hypertension (PIH) berat. Kemunculan komponen janin di dalam vaskular rahim juga bukanlah indikator yang definitif untuk EAK dengan DIC. ${ }^{6}$

Beberapa kriteria diagnostik telah dikembangkan untuk definisi EAK, sebagai contoh, kriteria entri register EAK Amerika Serikat, kriteria UK Obstetric Surveillance System (UKOSS) untuk definisi kasus EAK, dan kriteria konsensus Jepang untuk diagnosis EAK (tabel 2). Kriteriakriteria diagnostik ini memiliki perbedaan dalam gambaran klinis, interval waktu antara persalinan dan onset klinis gejala dan kriteria eksklusi. Perbedaan dalam kriteria diagnostik ini dapat menghasilkan kesimpulan diagnostik yang berbeda. Hingga kini masih belum ada konsensus internasional diantara peneliti mengenai definisi EAK. ${ }^{13}$ Society for Maternal-Fetal Medicine (SMFM) mengeluarkan rekomendasi pada tahun 2016. Rekomendasi dari SMFM antara lain untuk mempertimbangkan EAK sebagai diagnosis banding pada pasien dengan kolaps kardiorespiratorik mendadak saat dalam atau sesaat setelah persalinan. SMFM tidak merekomendasikan penggunaan tes laboratorium diagnostik spesifik untuk mengkonfirmasi atau menyingkirkan kemungkinan diagnosis EAK, dan untuk saat ini EAK masih menjadi diagnosis klinis. ${ }^{14}$

\section{Diagnosis Banding}

Emboli cairan amniotik pada dasarnya adalah diagnosis klinis dan diagnosis eksklusi karena tidak ada tes laboratorium yang tersedia untuk mengkonfirmasi diagnosis. Trias klasik berupa gangguan pernapasan, kolaps kardiovaskular, dan koagulopati. Kondisi serupa lainnya yang dapat menjadi diagnosis pembanding sebelum diagnosis EAK. Diagnosis banding EAK mencakup etiologi obstetrik, nonobstetrik, dan anestestik. $^{1}$

\section{Pemeriksaan Penunjang}

\section{Pemeriksaan radiologis}

Temuan radiografi thoraks posteroanterior dan lateral biasanya nonspesifik. Abnormalitas radiografis utama dalam EAK adalah area homogen dan heterogen bilateral difus dengan peningkatan opasitas, yang tidak bisa dibedakan dari edema pulmoner akut. ${ }^{1}$ Gambaran klinik radiologis dan keparahan penyakit mungkin bervariasi tergantung pada isi air ketuban dan status alergi host. CT-scan mungkin menemukan area dengan opasitas ground-glass multifokal bilateral yang tidak bisa dibedakan dari penyebab edema pulmoner akut lainnya. CT-scan mungkin juga menemukan penebalan septum interlobularis dan efusi pleura karena respon anafilaktik host. Meski diagnosis banding mencakup perdarahan pulmoner dan pneumonia aspirasi, kedua kondisi ini bisa muncul bersama 
Tabel 2. Beberapa kriteria diagnostik yang berbeda untuk EAK

\begin{tabular}{|c|c|c|}
\hline Kriteria AS & Kriteria Inggris & Kriteria Jepang \\
\hline Kriteria entri register US AFE & $\begin{array}{l}\text { Kriteria UK } \text { Obstetric } \\
\text { Surveillance System untuk } \\
\text { definisi kasus emboli air } \\
\text { ketuban }\end{array}$ & 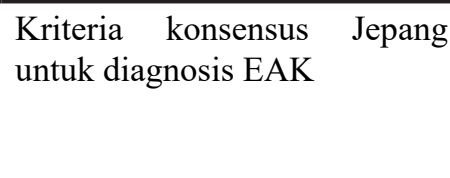 \\
\hline $\begin{array}{l}\text { 1. Hipotensi akut atau cardiac } \\
\text { arrest }\end{array}$ & $\begin{array}{l}\text { Jika tidak ada penyebab jelas } \\
\text { lain } \\
\text { 1. kolaps maternal akut }\end{array}$ & $\begin{array}{l}\text { 1. jika gejala muncul selama } \\
\text { kehamilan atau dalam } 12 \\
\text { jam setelah persalinan }\end{array}$ \\
\hline $\begin{array}{l}\text { 2. Hipoksia akut, didefinisikan } \\
\text { sebagai dispnea, sianosis } \\
\text { atau henti pernapasan }\end{array}$ & $\begin{array}{l}\text { dengan salah satu atau } \\
\text { beberapa fitur berikut: } \\
\text { gangguan fetal akut, } \\
\text { aritmia atau henti jantung, }\end{array}$ & $\begin{array}{l}\text { 2. jika intervensi medis } \\
\text { intensif dilakukan untuk } \\
\text { menangani salah satu atau }\end{array}$ \\
\hline $\begin{array}{l}\text { 3. Koagulopati, didefinisikan } \\
\text { sebagai bukti laborat } \\
\text { konsumsi intravaskular atau } \\
\text { fibrinolisis atau perdarahan } \\
\text { klinis berat yang tidak ada } \\
\text { penjelasan lain }\end{array}$ & $\begin{array}{l}\text { koagulopati, konvulsi, } \\
\text { hipotensi, perdarahan } \\
\text { maternal, gejala } \\
\text { premonitorik, seperti } \\
\text { restlessness, numbness, } \\
\text { agitasi, tingling, sesak } \\
\text { atau henti napas. }\end{array}$ & $\begin{array}{l}\text { beberapa gejala/penyakit } \\
\text { berikut: cardiac arrest, } \\
\text { perdarahan hebat tanpa } \\
\text { sumber jelas dalam } 2 \text { jam } \\
\text { setelah persalinan ( } \geq 1500 \\
\text { mL), DIC, gagal napas }\end{array}$ \\
\hline $\begin{array}{l}\text { 4. Onset gejala di atas selama } \\
\text { persalinan, SC atau dilatasi } \\
\text { dan evakuasi atau dalam } 30 \\
\text { menit post partum }\end{array}$ & $\begin{array}{l}\text { 2. eksklusi pasien dengan } \\
\text { perdarahan maternal } \\
\text { sebagai gejala awal jika } \\
\text { tidak ada bukti koagulasi } \\
\text { awal atau gangguan }\end{array}$ & $\begin{array}{l}\text { 3. jika temuan atau gejala } \\
\text { yang ada tidak bisa } \\
\text { dijelaskan oleh penyakit } \\
\text { lain }\end{array}$ \\
\hline $\begin{array}{l}\text { 5. Tidak ada kondisi signifikan } \\
\text { lain atau kemungkinan } \\
\text { penjelasan lain terhadap } \\
\text { gejala dan tanda yang } \\
\text { ditemukan }\end{array}$ & $\begin{array}{l}\text { kardiorespiratorik } \\
\text { Atau } \\
\text { 3. pasien dimana diagnosis } \\
\text { ditegakkan dengan } \\
\text { pemeriksaan post mortem }\end{array}$ & $\begin{array}{l}\text { 4. untuk EAK, koagulopati } \\
\text { konsumtif/DIC karena } \\
\text { etiologi jelas seperti } \\
\text { plasentasi abnormal, } \\
\text { trauma selama persalinan } \\
\text { dan kelahiran dan }\end{array}$ \\
\hline $\begin{array}{l}\text { *Pasien yang memenuhi } \\
\text { semua kriteria lain termasuk } \\
\text { cardiorespiratory arrest } \\
\text { yang meninggal sebelum } \\
\text { koagulopati bisa diidentifikasi, } \\
\text { dimasukkan ke dalam analisis } \\
\text { primer }\end{array}$ & $\begin{array}{l}\text { berdasarkan temuan } \\
\text { skuamosa atau rambut } \\
\text { janin di paru }\end{array}$ & $\begin{array}{l}\text { preeklampsia berat/ } \\
\text { eklampsia, harus } \\
\text { dieksklusi }\end{array}$ \\
\hline
\end{tabular}

Dikutip dari: Kobayashi H, $2017^{13}$

emboli air ketuban karena kemungkinan adanya penyakit komorbid yang menyertai termasuk eklampsia, aspirasi, dan PTE. Selain itu, gestational trophoblastic disease, yang terjadi karena proliferasi abnormal epitelium trophoblast plasenta, seharusnya juga dipertimbangkan sebagai salah satu diagnosis banding emboli air ketuban. ${ }^{15}$ Peran CT-scan dalam diagnosis EAK terbatas karena temuan yang relatif nonspesifik, tetapi CT-scan dapat digunakan untuk membantu menyingkirkan kemungkinan penyebab alternatif atau memunculkan kemungkinan diagnosis EAK. Mikroemboli dalam EAK biasanya terlalu kecil untuk diidentifikasi, bahkan dengan CT pulmonary angiography. Gambaran beresolusi tinggi ini mungkin akan menemukan nodul ground-glass sentrilobuler dengan batas tidak tegas dengan predileksi di paru bawah (gambar 4).

Diagnosis banding utama antara lain penyebab edema pulmoner akut atau perdarahan 
Table 3. Diferensial diagnosis emboli air ketuban $^{4}$

\begin{tabular}{l}
\hline Penyebab non obstetri \\
\hline Emboli pulmonal (udara, lemak, thrombus) \\
Edema pulmo \\
Emboli kolesterol \\
Diseksi aorta \\
Tension pneumothorax \\
Infeksi miokardial, gagal jantung, aritmia, \\
tamponade \\
anafilaksi \\
syok septik \\
Aspirasi isi lambung \\
Penyebab yang berhubungan dengan anestesi-obat \\
local anestesi toksisitas, high spinal \\
Penyebab reversible yang lain - toxins, hipo/ \\
hiperkalemia \\
metabolik \\
hypothermia \\
Penyebab Obstetri \\
Eklamsia \\
Abruptio placenta \\
Rupture uteri \\
Perdarahan postpartum \\
\hline peripartum cardiomiopathy \\
\hline atipdari Girendat
\end{tabular}

Dikutip dari: Girendra ${ }^{4}$

pulmoner difus, peran utama CT scan adalah untuk menunjukkan kemungkinan kelainan lain yang tampak berbeda dari EAK, termasuk tromboemboli vena, pneumonia, dan aspirasi. ${ }^{16}$ Emboli air ketuban mungkin juga memiliki manifestasi neurologis pada otak yang mungkin ditandai dengan temuan radiologis berupa hipoksemia serebral umum dan iskemia karena hipoperfusi atau emboli serebri multipel karena gagal jantung kiri sekunder atau right-toleft shunt. Transformasi hemoragik dini pada lesi iskemik bisa ditemukan. ${ }^{10}$ Pemeriksaan transesophageal echocardiography (TEE) mungkin dapat membantu diagnosis dini dengan menunjukkan vasokonstriksi pulmoner akut, dilatasi ventrikel kanan, dan kolaps ventrikel kiri dengan deviasi septum intraventrikular ke kiri. Akan tetapi, akses langsung ke TEE mungkin tidak tersedia di banyak unit obstetrik. ${ }^{1}$
Tabel 4. Biomarker yang telah digunakan dalam diagnosis emboli air ketuban

\begin{tabular}{|c|c|}
\hline \multicolumn{2}{|c|}{ Biomarker yang ada } \\
\hline \multirow[t]{3}{*}{$\begin{array}{l}\text { Zinc } \\
\text { coproporphyrin }\end{array}$} & $\begin{array}{l}\text { Komponen karakteristik dari } \\
\text { meconium dan urine janin }\end{array}$ \\
\hline & Meningkat saat EAK \\
\hline & $\begin{array}{l}\text { Terdeteksi melalui cairan } \\
\text { kinerja tinggi } \\
\text { kromatografi }\end{array}$ \\
\hline \multirow[t]{2}{*}{$\begin{array}{l}\text { Sialosyl Tn } \\
\text { antigen }\end{array}$} & $\begin{array}{l}\text { Antigen janin ditemukan di } \\
\text { mekonium dan cairan ketuban }\end{array}$ \\
\hline & $\begin{array}{l}\text { Terdeteksi melalui monoclonal } \\
\text { TKH-2 antibodi }\end{array}$ \\
\hline \multirow[t]{2}{*}{ Tryptase } & Marker degranulasi sel mast \\
\hline & $\begin{array}{l}\text { Meningkat pada beberapa } \\
\text { pasien EAK }\end{array}$ \\
\hline \multirow[t]{2}{*}{$\begin{array}{l}\text { Complement } \\
\text { factors }\end{array}$} & $\begin{array}{l}\text { Penurunan komplemen } \mathrm{C} 3 \text { dan } \\
\mathrm{C} 4\end{array}$ \\
\hline & $\begin{array}{l}\text { Kemungkinan aktivasi } \\
\text { pelengkap }\end{array}$ \\
\hline \multirow[t]{2}{*}{ Cytokines } & $\begin{array}{l}\text { IL-6, IL-8, dan tumor necrosis } \\
\text { factor meningkat pada } \\
\text { beberapa pasien EAK }\end{array}$ \\
\hline & $\begin{array}{l}\text { Tidak spesifik karena bisa } \\
\text { adadalam respon inflamasi } \\
\text { sistemik sindroma }\end{array}$ \\
\hline \multirow{2}{*}{$\begin{array}{l}\text { Insulin-like } \\
\text { growth factor } \\
\text { binding protein } 1\end{array}$} & $\begin{array}{l}\text { Protein perkembangan embrio } \\
\text { disintesis dalam desidua }\end{array}$ \\
\hline & $\begin{array}{l}\text { Dapat dideteksi dalam cairan } \\
\text { amnion dan } \\
\text { serum ibu }\end{array}$ \\
\hline
\end{tabular}

Dikutip dari: Balinger $\mathrm{KJ}^{4}$

\section{Pemeriksaan Laboratorium}

Evaluasi diagnostik awal seharusnya mencakup pulse oximetry kontinyu dan arterial blood gas (ABG) untuk menentukan derajat hipoksemia. Nilai ABG menunjukkan perubahan yang konsisten dengan hipoksia atau hipoksemia, ditandai dengan penurunan $\mathrm{pH}$, penurunan $\mathrm{PO}_{2}$, peningkatan kadar $\mathrm{PCO}_{2}$, peningkatan kelebihan basa. Hitung darah lengkap dan pemeriksaan koagulasi secara serial seharusnya dilakukan untuk mengikuti tren dan mendeteksi koagulopati dini. Kadar hemoglobin dan hematokrit seharusnya 
Tabel 5. Biomarker yang masih diteliti untuk diagnosis emboli air ketuban

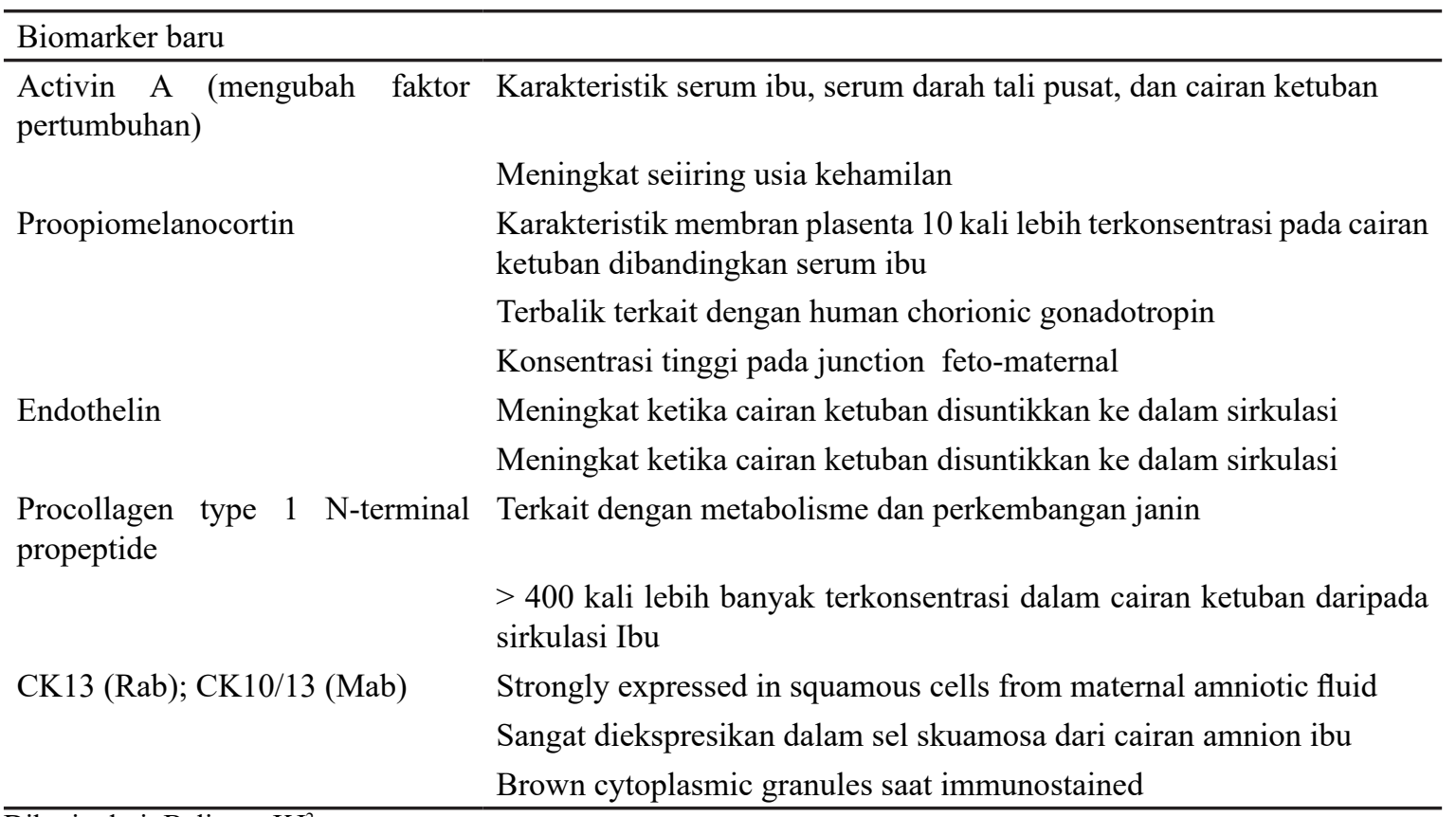

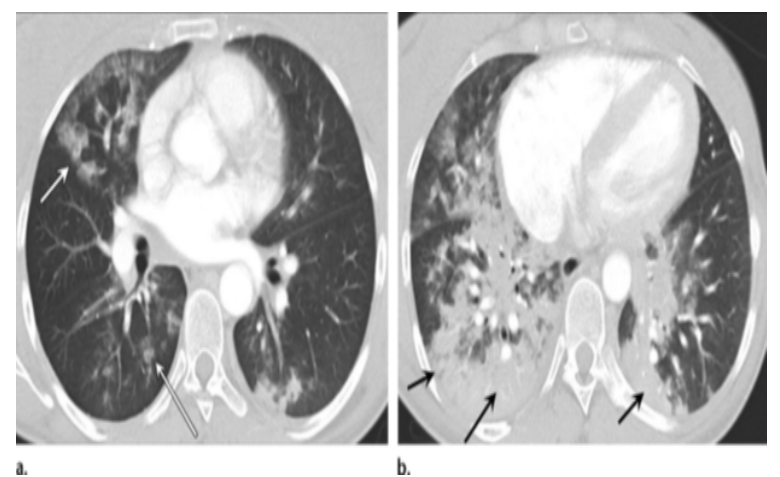

Gambar 4. Gambar CT thorak aksial pada pasien wanita berusia 28 th pada periode postpartum setelah persalinan pada usia kehamilan 32 minggu yang menunjukkan opasitas ruang udara nodular dengan batas tidak tegas (panah a) dan konfluen (panah b) yang konsisten dengan emboli air ketuban. Salah satu temuan CT penting adalah nodul ground glass yang terkait dengan arteriola terminal. Ini menandakan sekuele dari pneumonitas kimiawi karena cairan emboli. Filling defect intra-arterial hampir tidak pernah ditemukan dalam kondisi ini. ${ }^{16}$

dalam rentang referensi, dan trombositopenia jarang terjadi. Pemeriksaan koagulasi darah akan menemukan pemanjangan prothrombin time (PT) karena faktor pembekuan darah telah habis dan

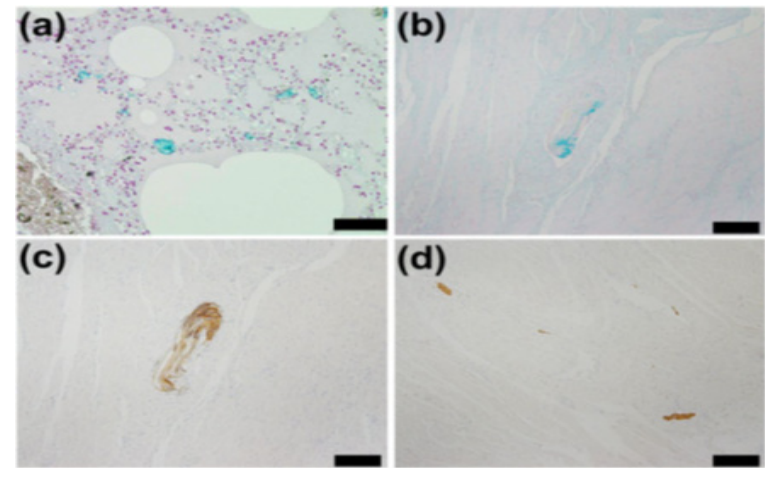

Gambar 5. Irisan histopatologis paru (A) dan uterus (B). Pengecatan positif dengan pewarnaan Alcian blue (A) dan (B), AE1/AE3 cytokeratin positif (B), dan $\mathrm{ZnCP-1}$ positif (D) dalam pembuluh darah. ${ }^{6}$

activated partial thromboplastin time (aPTT) mungkin dalam rentang referensi atau memendek. Intervensi diindikasikan jika PT 1,5 kali nilai kontrol. Kadar fibrinogen harus dimonitor jika memungkinkan. ${ }^{1}$

\section{Pemeriksaan Histologis}

Teknik pemeriksaan histologis dalam EAK Komponen janin bisa diidentifikasi dengan pengecatatan hematoksilin eosin rutin 
berdasarkan kemunculan sel skuamosa epitelial, rambut lanugo, dan lemak dari vernix atau infantile mucin di dalam bantalan vaskuler pulmoner ibu atau jaringan lainnya. Beberapa pengecatan lain yang digunakan untuk mengkonfirmasi EAK adalah alcian blue untuk mendeteksi air ketuban, pengecatan cytokeratin AE1/AE3 untuk mendeteksi sel skuamosa janin dan pengecatan $\mathrm{ZnCp}-1$ untuk mendeteksi mekonium, dan pengecatan reseptor C5a (CD88) untuk mendeteksi aktivasi komplemen dan pembentukan anafilatoksin di dalam berbagai organ. ${ }^{6}$

\section{Histologi Paru}

Temuan yang sering muncul dalam pemeriksaan otopsi pasien EAK antara lain edema pulmoner, kongesti, dan atelektasis fokal. Komponen ketuban terdeteksi di dalam pembuluh darah pulmoner dengan pengecatan alcian blue atau $\mathrm{ZnCp}-1$. Pengecatan AE1/AE3 cytokeratin jaringan paru juga menunjukkan positivitas intravaskuler intens terhadap sel skuamosa fetal, dan peningkatan jumlah mast cell pulmoner diidentifikasi dan diukur secara immunohistokimia. Pengecatan immunohistokimia terhadap CD88 positif dalam sel stroma di sekitar kapiler pulmoner dan sel inflamatorik di dalam alveolus. Hanya $10-15 \%$ kasus EAK memiliki tipe kolaps kardiopulmoner, dimana materi janin menyebabkan obstruksi fisik di dalam pembuluh darah mikro maternal di berbagai organ seperti paru. Sisanya disebabkan karena reaksi anafilaktoid yang mengakibatkan vasospasme pulmoner, edema, dan aktivasi trombosit, leukosit, dan komplemen. Dalam kasus seperti ini, bahkan masuknya air ketuban dalam jumlah kecil menyebabkan gambaran klinis EAK oleh reaksi anafilaktoid, diduga sebagai reaksi CD88-positif. ${ }^{6}$

Uterus

Tipe EAK DIC didefinisikan sebagai kondisi patologis tanpa ada bukti komponen ketuban di dalam paru, tetapi memenuhi kriteria untuk EAK klinis dengan kemunculan postpartum hemorrhage (PPH) tanpa etiologi yang diketahui akibat atoni uteri dengan bukti komponen janin di dalam pembuluh darah uteri. Beberapa laporan menunjukkan kaitan yang erat antara atoni uteri dan EAK. PPH dengan penyulit koagulabilitas rendah yang diketahui sebagai PPH tipe DIC juga muncul akibat atoni uteri. Dalam kasus-kasus seperti ini, atoni uteri bisa ditemukan secara makroskopis dengan uterus yang mengalami edema besar. Aliran lokal air ketuban ke dalam jaringan rahim dapat menyebabkan reaksi anafilaktoid di dalam uterus, menyebabkan edema uterus. Untuk EAK tipe DIC, marker SzCp-1 dan STN serum tidak selalu sensitif; tetapi komponen mucin yang diidentifikasi dengan pengecatan alcian blue dan $\mathrm{ZnCp}-1$ dari mekonium terdeteksi di dalam pembuluh darah uterus. ${ }^{6}$

\section{Biomarker}

Deteksi sel skuamosa atau debris lainnya dalam bantalan arterial pulmoner maternal tidak lagi dianggap diagnostik untuk EAK. Degranulasi mast cell ditemukan dalam paru maternal dalam kasus EAK fatal tetapi tidak ditemukan dalam kematian persalinan karena sebab lain. Apakah degranulasi mast cell adalah proses primer atau sekunder karena aktivasi komplemen masih belum diketahui. Degranulasi mast cell menyebabkan pelepasan tryptase, histamine, bradykinin, endothelin, leukotriene, dan metabolit arachidonic acid. Kadar tryptase serum dalam kasus EAK fatal diketahui meningkat 7-10 kali lebih tinggi daripada kontrol. Peningkatan tryptase juga telah dikaitkan dengan reaksi anafilaksis dan seharusnya dibedakan dari EAK. ${ }^{11}$ Air ketuban telah diketahui mengaktifkan komplemen di dalam model eksperimental. Komplemen bekerja melalui jalur klasik atau secara tidak langsung melalui pelepasan peptida anafilaktoid. Produk aktivasi komplemen C3a dan C5a berikatan dengan reseptor immunoglobulin affinitas tinggi yang diekspresikan pada membran mast cell. Komplemen mungkin bisa menjadi biomarker yang handal. Akan tetapi, kadar komplemen mungkin menurun setelah kelahiran, dan kadar komplemen pada pasien kritis nonEAK masih belum diketahui. ${ }^{11}$

Sialyl-Tn (STN) adalah komponen mekonium dan mucin yang berasal dari air ketuban. Kemunculan STN dalam serum maternal pada pasien suspek EAK adalah tes diagnostik direk yang memastikan bahwa mucin dari ketuban telah melintas ke dalam sirkulasi maternal. Kadar 
komplemen $\mathrm{C} 3$ dan $\mathrm{C} 4$ yang rendah bersama dengan kadar STN tinggi telah dikaitkan dengan aktivasi komplemen. $\mathrm{C} 1$ esterase inhibitor (C1 $\mathrm{INH}$ ) adalah inhibitor utama $\mathrm{C} 1$ esterase, aktivasi faktor XII dan kallikrein. Tingkat aktivitas C1 INH menunjukkan penurunan signifikan dalam kasus fatal dibandingkan kasus nonfatal, menunjukkan bahwa C1 INH mungkin merupakan faktor penting dalam kemunculan koagulopati dan mungkin adalah biomarker diagnostik atau prognostik penting di masa depan. ${ }^{11}$

Sejumlah biomarker yang telah digunakan dan yang masih diteliti untuk diagnosis emboli air ketuban ditampilkan di dalam tabel di bawah (tabel 4 dan tabel 5). Potensi diagnostik dari profil protein, lipid dan transcriptomic vesikel ekstraseluler telah diteliti. Vesikel ini mengalami ekstrusi ke dalam sirkulasi maternal pada awal perjalanan EAK, pada saat sebelum manifestasi klinis muncul, membuat mereka mungkin berguna dalam diagnosis dini. Akan tetapi, sensitivitas dan spesifisitas tes-tes ini rendah, sehingga belum digunakan dalam klinis. ${ }^{2}$

\section{Penatalaksanaan}

Untuk mencegah EAK, trauma pada uterus harus dihindari selama manuver seperti insersi pressure catheter atau ruptur membran. Insisi plasenta selama persalinan sesar seharusnya juga dihindari jika memungkinkan. Karena salah satu faktor predisposisi adalah persalinan sulit yang mungkin terjadi secara alami, kontraksi rahim yang terlalu kuat dan sering seharusnya dikendalikan dengan pemberian obat $\beta$-adrenergik intravena atau magnesium sulfat. Selain itu, obat oksitosik yang dapat memicu kontraksi uteri tetanik berlebihan harus digunakan sesuai indikasi. ${ }^{1}$ Identifikasi dini EAK penting untuk keberhasilan penatalaksanaan pasien. Penatalaksanaan emboli air ketuban terutama adalah dengan resusitasi dan seharusnya diarahkan untuk mengendalikan jalan napas, mempertahankan tanda vital dan koreksi koagulopati. EAK selalu disertai dengan hipoksia. Dengan demikian, pengendalian jalan napas dengan intubasi trakeal dan pemberian $\mathrm{O}_{2}$ $100 \%$ dengan ventilasi tekanan positif seharusnya dilakukan sedini mungkin. Akses vena dengan kateter IV berdiameter besar seharusnya dilakukan tanpa ada penundaan. Kateterisasi arterial seharusnya juga dipertimbangkan untuk monitoring tekanan darah arterial yang akurat dan sampling darah yang sering. ${ }^{9}$

SMFM mengeluarkan beberapa rekomendasi tentang penatalaksanaan EAK antara lain penyediaan resusitasi jantung paru yang berkualitas tinggi dengan protokol BCLS dan ACLS standar pada pasien yang mengalami cardiac arrest yang menyertai EAK, serta melibatkan sebuah tim multidisiplin yang terdiri dari dokter anestesi, terapi respiratorik, critical care, maternal-fetal dalam penatalaksanaan. Ketika terjadi cardiac arrest dengan EAK, SMFM merekomendasikan untuk mempercepat persalinan jika usia kehamilan $\geq 23$ minggu. SMFM juga merekomendasikan pemberian oksigen dan ventilasi yang adekuat dan, jika ada indikasi berdasarkan status hemodinamik, untuk menggunakan vasopresor dan obat inotropik dalam manajemen awal EAK. Pemberian cairan yang berlebihan harus dihindari. Karena koagulopati bisa terjadi setelah kolaps kardiovaskular pada EAK, SMFM merekomendasikan asesmen dini status pembekuan darah dan manajemen perdarahan klinis secara agresif dengan protokol transfusi masif standar. ${ }^{14}$ Anderson $\mathrm{dkk}^{5}$ membagi penatalaksanaan EAK menjadi tiga fase, berdasarkan periode menjadi terapi immediate, fase intermediate, dan manajemen lanjutan. Penatalaksanaan dalam fase immediate memprioritaskan pada resusitasi untuk mengembalikan oksigenasi dan sirkulasi. Fase intermediate memfokuskan pada mengembalikan stabilitas hemodinamik dan meninjau ulang diagnosis. Fase lanjutan bersifat suportif dengan penanganan lanjutan pasien dilakukan di ICU.

1. Terapi immediate (segera)

a. Pastikan patensi jalan napas

Ketika terjadi kolaps, airway pasien gravid sangat berisiko untuk gangguan jalan napas dan komplikasi seperti Mendelson's syndrome karena melambatnya pengosongan lambung. Resusitasi kardiopulmoner (CPR), jika memang diperlukan, akan meningkatkan tekanan intraabdominal sehingga meningkatkan risiko. Dokter harus mempertahankan patensi jalan napas. 
Pertimbangkan intubasi khususnya jika pasien masih hamil, memerlukan CPR, atau berisiko untuk kolaps kardiorespiratorik (seperti hipoksia berat).

b. Mempertahankan oksigenasi

Pada pasien yang bernapas secara spontan, berikan oksigen aliran tinggi ( $>12 \mathrm{~L} /$ menit) dengan non-rebreathing mask dengan reservoir bag. Karena uterus gravid menggeser visera abdomen, pulmonary functional reserve capacity biasanya menurun hingga 20\% dalam kehamilan. Peningkatan tingkat pernapasan fisiologis yang diperantarai progesterone terjadi selama kehamilan, sehingga pasien memiliki minute alveolar volume yang lebih tinggi meski terdapat pergeseran diafragmatik $4 \mathrm{~cm}$. Ketika terjadi respiratory distress, mekanisme kompensatorik berkurang. ${ }^{4}$

Dengan demikian, manajemen hipoksia harus dilakukan dengan cepat dan agresif sesuai dengan gambaran klinis. Ventilasi tekanan positif invasif dengan endotracheal tube diperlukan dalam kasus distres pernapasan berat, atau ketika akan terjadi atau sudah terjadi cardiorespiratory arrest. Pertimbangkan penggunaan positive endexpiratory pressure, khususnya jika ada edema paru kardiogenik dan non-kardiogenik. ${ }^{4}$

\section{c. Support kardiovaskular}

Pasien EAK rentan terhadap kolaps sirkulatorik mendadak karena gagal jantung kanan akut, gagal jantung kiri, aritmia jantung, emboli pulmoner, dan pergeseran cairan mendadak yang menyertai perdarahan masif dan/atau DIC. CPR seharusnya dimulai segera jika terjadi cardiac arrest. Monitoring kontinyu dan manajemen agresif menjadi dasar untuk support kardiovaskular pada pasien EAK. Monitoring seharusnya mencakup EKG kontinyu dan tekanan darah invasif di ruang ICU, dengan pengambilan sampel darah untuk hitung darah lengkap, koagulasi, urea dan elektrolit, dan crossmatching. Monitor cardiac output dan transesophageal echocardiography mungkin memberikan informasi berguna dalam manajemen syok yang dipicu EAK. Perawatan suportif seharusnya dilakukan secara individual dan mungkin mencakup dua kanula intravena diameter besar, menggantikan cairan intravaskular yang hilang dengan kristaloid, koloid, dan produk darah. Aritmia yang ditemukan harus ditangani, dengan pertimbangan khusus untuk kemungkinan abnormalitas elektrolit. Pemberian vasopresor, kronotropik, dan/atau obat inotropik dipandu oleh monitoring cardiac output. Penggunaan alat cardiopulmonary bypass extracorporeal membrane oxygenation, dan intra-aortic balloon pump telah dilapoprkan dalam manajemen kolaps kardiovaskuler yang dipicu EAK. ${ }^{4}$

\section{d. Persalinan janin}

Jika CPR dilakukan, keberhasilannya bisa terganggu oleh uterus gravid yang membuat kompresi dada menjadi sulit dan mengurangi venous return jantung meski dengan posisi left lateral tilt. Ada bukti kuat bahwa ibu hamil lebih rentan terhadap kerusakan otak hipoksik ketika terjadi kolaps sirkulatorik. CPR berkualitas tinggi adalah sangat penting dalam mencegah kerusakan otak ini jika pasien survive. Hingga saat ini, jika CPR tidak berhasil setelah 3 menit, rencana untuk persalinan darurat harus dilakukan. Akan tetapi, intervensi ini harus dilakukan untuk membantu terapi maternal, tidak tergantung pada kondisi janin, termasuk janin yang sudah meninggal in utero. Jika persalinan dengan instrumen tidak memungkinkan, persalinan sesar darurat harus dilakukan. Pertimbangan sterilitas dan diseksi anatomis yang tepat menjadi kurang penting dibandingkan mempercepat persalinan, dan dokter spesialis hanya akan memerlukan sebuah scalpel. Teknik Hoel-Cohen atau teknik yang mirip lainnya dapat digunakan, atau teknik apapun yang nyaman bagi dokter. Persalinan janin, meski diperlukan, sepertinya semakin memperberat masalah yang muncul karena DIC. Perdarahan kemungkinan akan terjadi. ${ }^{4}$

\section{Fase intermediate}

a. Koreksi hipoperfusi

Pertimbangkan untuk monitor cardiac output, khususnya jika ada edema paru, instabilitas hemodinamik, dan hipoperfungsi organ akhir. ${ }^{4}$

\section{b. Koreksi koagulopati}

Transfusi darah dan produk darah sering diperlukan dalam penatalaksanaan EAK. Tujuan 
dari penatalaksanaan seharusnya mengembalikan dan mempertahankan profil koagulasi normal. Dalam survey UKOSS, tujuh wanita dengan EAK berhasil ditangani dengan transfusi plasma exchange. Diduga pembuangan sitokin, debris seluler, dan produk sampingan koagulasi dapat memperantarai dan memperpendek dampak dari respon humoral. Asidosis, hipokalsemia, dan hipotermia seharusnya juga dikoreksi. Karena jumlah pasien yang terlibat sedikit, bukti untuk manfaat survival atau penurunan morbiditas masih belum jelas. ${ }^{4}$

\section{c. Tonus uteri}

Ketika terjadi perdarahan postpartum yang menyertai, apakah ada DIC atau tidak, harus dipertimbangkan untuk menggunakan obat uterotonik untuk membatasi darah yang hilang dan mempertahankan volume sirkulasi. Opsi surgikal, termasuk histerektomi darurat, bisa dilakukan jika perlu. ${ }^{4}$

\section{d. Pemeriksaan lanjutan}

Lakukan x-ray thoraks. Dalam banyak kasus EAK, gambaran x-ray pasien akan menunjukkan shadowing yang konsisten dengan ARDS, tetapi gambaran ini membaik dalam waktu singkat. ${ }^{4}$

\section{e. Diagnosis retrospektif}

EAK sebelumnya didiagnosis berdasarkan kemunculan sel skuamosa janin di dalam sirkulasi maternal postmortem. Akan tetapi, seiring meningkatnya tingkat survival EAK, diagnosis menjadi semakin klinis. Kolaps maternal bisa disebabkan karena sejumlah diagnosis banding. Pada saat terjadi kolaps maternal, terapi akan saling tumpang tindih apapun diagnosisnya, dan ketidakpastian diagnosis seharusnya tidak menunda treatment. Setelah resusitasi, diagnosis menjadi penting kembali, beberapa penyebab mungkin memerlukan penatalaksanaan khusus. Diagnosis EAK adalah diagnosis eksklusi. Dengan demikian, EKG harus dilakukan, dan pemeriksaan gas darah arterial ulang, hitung darah lengkap, dan profil pembekuan darah diperlukan bersama dengan tes fungsi hati dan elektrolit serum. Echokardiogram seharusnya dipertimbangkan untuk menyingkirkan kemungkinan masalah miokardial. Ventilation perfusion scan atau computed tomography pulmonary angiography akan menegakkan atau menyingkiirkan kemungkinan abnormalitas seperti emboli pulmoner. Kadar zinc coproporphyrin dan tryptase tidak digunakan dalam diagnosis EAK karena hasil yang berlawanan dalam literatur tentang penggunaannya dalam membantu diagnosis. ${ }^{4}$

\section{Manajemen lanjutan}

Setelah episode kolaps maternal dan keberhasilan resusitasi, transfer ke ICU seharusnya dilakukan dan satu-satunya treatment untuk EAK adalah bersifat suportif. Kegagalan pemberian perawatan ini akan menurunkan survival. Suport inotropik seharusnya dipertimbangkan jika ada penurunan fungsi jantung. Monitoring arteri pulmonalis mungkin diperlukan. Setelah tekanan darah membaik, restriksi cairan mungkin diperlukan untuk mencegah overload cairan. Karena EAK menyerupai proses anafilaktoid, penggunaan adrenalin dan hidrokortison telah diusulkan, tetapi hingga kini belum ada literatur yang mendukungnya. ${ }^{4}$

\section{Terapi Farmakologis}

Vasopresor dan suport inotropik biasanya diperlukan dalam EAK. Akses vena sentral harus dibuat untuk infusi vasopresor dan monitoring. Pilihan obat vasopresor tergantung pada skenario klinis. ${ }^{1}$

- Epinefrin mungkin adalah obat pilihan pertama karena digunakan dalam reaksi anafilaktoid lainnya, selain efek vasokonstriktor $\alpha$-adrenergik yang dimiliki.

- Phenylephrine, agonis $\alpha-1$ murni, sering menjadi pilihan pada awal treatment EAK karena pada titik waktu ini vasodilatasi sistemik adalah abnormalitas sirkulatorik yang paling menonjol.

- Support inotropik seperti dopamine atau noradrenaline mungkin merupakan obat yang ideal karena efek $\beta$-adrenergik tambahan, yang dapat memperbaiki fungsi jantung.

- Vasopressin mungkin dapat diberikan sebagai terapi primer atau sebagai tambahan untuk terapi inotropik lainnya dan memiliki manfaat membuat vaskularisasi pulmoner terhindar dari vasokonstriksi, khususnya pada dosis 
rendah. Ketika terdapat gagal jantung kanan, milrinone atau inhibitor phosphodiesterase lainnya seharusnya dipertimbangkan.

- Digoxin bekerja secara langsung pada otot jantung dan sistem konduksi. Digoxin menyebabkan peningkatan dalam tenaga dan kecepatan kontraksi sistolik, perlambatan denyut jantung, dan penurunan kecepatan konduksi melalui nodus AV.

- Hydrocortisone. Karena EAK lebih mirip dengan reaksi anafilaktik, direkomendasikan untuk memberikan steroid yang memperatarai respon imun.

- Oxytocin. Uterotonik ini menurunkan inflamasi dengan menekan migrasi leukosit polimorfonuklear dan membalikkan permeabilitas kapiler.

- Methylergovonine (methergine). Bekerja secara langsung pada otot polos uteri, menyebabkan efek uterotonik tetanik menetap yang menurunkan perdarahan uterus.

- Carboprost tromethamine. Prostaglandin yang mirip dengan F2- $\alpha$ (dinoprost), tetapi memiliki durasi yang lebih lama dan menghasilkan kontraksi miometrial yang memicu hemostasis di lokasi plasentasi, yang menurunkan perdarahann postpartum.

- Keberhasilan penggunaan faktor VIIa rekombinan (rfVIIa) telah dilaporkan, meski telah dikaitkan dengan trombosis intravaskular masif.

- Aprotonin juga telah dilaporkan efektif dalam menurunkan perdarahan dengan EAK.

- Obat antifibrinolitik lainnya, seperti aminocaproic acid dan tranexamic acid, yang telah dijelaskan dalam manajemen perdarahan obstetrik dan menorrhagia dan juga mungkin dipertimbangkan selama EAK. ${ }^{4}$

\section{Perimortem Seksio Sesarea}

Persalinan sesar perimortem pada kasus henti jantung ibu sangat penting dalam resusitasi ibu dan juga dalam menyelamatkan janin. Royal College of Obstetricians and Gynecologists guideline menyatakan bahwa operasi sesar perimortem harus dilakukan dalam kasus henti jantung ibu ketika tidak terjadi kembalinya sirkulasi spontan setelah 4 menit CPR efektif dan janin harus dilahirkan dalam 5 menit setelah henti jantung. Kelangsungan hidup janin tidak menjadi masalah dalam kasus-kasus seperti itu. Harus segera dilakukan ditempat itu dan tanpa memindah pasien ke ruang operasi. Dalam kasus ketidakstabilan kardiopulmoner tanpa serangan jantung yang jelas, peran seksio sesarea masih kontroversial. Jika tidak dikirim, janin berisiko mengalami hipoksia dan kematian intrauterus. ${ }^{4}$

\section{Strategi Baru Lain}

Konsentrat antithrombin sebelumnya telah dijelaskan dalam treatment koagulopati pada pasien obstetrik, dan dapat menyebabkan perbaikan outcome pada pasien dengan EAK yang mengalami koagulopati. Heparin juga telah diusulkan untuk treatment fase konsumtif DIC; tetapi, karena risiko terjadinya perdarahan masif dalam EAK, heparin untuk saat ini tidak direkomendasikan. ${ }^{11}$ Pada pasien dengan kolaps kardiopulmoner akibat EAK yang tidak merespon terhadap medikasi dan intervensi advance life support, support hemodinamik invasif mungkin membantu. Extracorporeal membrane oxygenation, cardiopulmonary bypass, intra-aortic balloon pump, pumonary artery thromboembolectomy, hemofiltrasi, dan transfusi plasma exchange telah disebutkan dalam berbagai laporan kasus, dan meski tidak terbukti dan bersifat eksperimental, mungkin bisa dipertimbangkan pada pasien yang tidak merespon terhadap intervensi resusitasi awal. Penggunaan plasma exchange mungkin berhubungan dengan pembuangan mediator kimia dan sitokin yang bertanggung jawab atas respon anafilaktoid. Kortikosteroid dosis tinggi untuk dugaan respon anafilaktoid yang diperantarai inflamasi juga telah diajukan. Treatment baru lainnya adalah penggunaan inhibitor $\mathrm{Cl}$ esterase sintetis (C1NH). C1NH menghambat X1 esterase, faktor XIIa, dan aktivasi komplemen. ${ }^{11}$

\section{Prognosis}

Survival setelah EAK telah mengalami perbaikan signifikan melalui identifikasi dini dan langkah resusitasi yang cepat dan dini. Sebelumnya, tercatat $50 \%$ pasien meninggal dalam satu jam 
pertama dan sekitar dua per tiga dalam 5 jam setelah kejadian dengan tingginya insidensi kerusakan neurologis berat dan permanen pada pasien yang survive. ${ }^{17}$ Meskipun tingkat mortalitas telah menurun, morbiditas masih tetap tinggi dengan sekuele berat. Selain gangguan neurologis, gagal ginjal oligurik atau nonoligurik akut, gagal jantung dengan gangguan ventrikel kiri, edema pulmoner kardiogenik, aritmia, iskemia atau infark miokardial telah dilaporkan. Gagal napas edema pulmoner nonkardiogenik dan bronkospasme refraktorik adalah sekuele lain yang telah dilaporkan. ${ }^{1}$

- Prognosis setelah EAK sangat buruk, dan sebagian besar ibu tidak survive

- Jika pasien survive dari embolisme, sebagian besar survivor memiliki defisit neurologis

- Tingkat survival bayi adalah sebesar $70 \%$. Status neurologis bayi terkait langsung dengan jeda waktu antara maternal arrest dan persalinan

- Risiko rekurensi masih belum diketahui. Keberhasilan kehamilan selanjutnya telah dilaporkan

EAK membawa risiko yang signifikan pada janin. Bukti awal menunjukkan bahwa sekitar setengah dari bayi yang lahir dari ibu yang meninggal karena EAK juga akan meninggal, dan hingga $20 \%$ bayi yang lahir dari ibu yang survive dari EAK akan meninggal. Dari bayi yang masih hidup, sekitar sepertiganya akan mengalami serebral palsi. Informasi terkini menunjukkan bahwa EAK berhubungan dengan tingkat mortalitas perinatal sebesar 135 per 1000 kasus. ${ }^{5}$

\section{Simpulan}

Emboli cairan amnion tetap merupakan diagnosis klinis eksklusi dan manajemennya berupa supportif. Tidak ada faktor risiko yang jelas terbukti untuk memprediksi atau mencegah terjadinya EAK. Meskipun angka kematian telah menurun selama bertahun-tahun karena resusitasi dan perawatan kritis yang lebih baik, masih tetap tinggi pada $12,8 \%$. Cahaya harapan yang menggembirakan adalah peningkatan barubaru ini dalam penelitian untuk menemukan patogenesis yang tepat dari kondisi ini dan juga untuk menemukan biomarker yang relevan secara klinis yang dapat membantu dalam diagnosis dini dan pengobatan yang cepat. Emboli air ketuban atau lebih tepatnya anaphylactoid syndrome of pregnancy adalah salah satu komplikasi kehamilan yang jarang terjadi tetapi paling membahayakan. Kondisi ini disebabkan karena reaksi imun/anafilaktoid maternal terhadap material fetal. Hingga saat ini, diagnosis bersifat klinis dan merupakan diagnosis eksklusi setelah menyingkirkan kemungkinan penyebab lain. Pemeriksaan penunjang seperti $\mathrm{x}$-ray dan CTscan memiliki keterbatasan karena gambaran yang nonspesifik. Penggunaan biomarker juga dibatasi oleh sensitivitas dan spesifisitas yang rendah. Outcome pasien sangat tergantung pada identifikasi dini dan penatalaksanaan yang dini dan agresif. Penelitian masih diperlukan untuk mengetahui secara pasti patofisiologi penyakit dan penatalaksanaannya.

\section{Daftar Pustaka}

1. Kaur K, Bhardwaj M, Kumar P, Singhal $\mathrm{S}$, Singh T, Hooda S. Amniotic fluid embolism. J Anaesthesiol Clin Pharmacol. 2016;32(2):153.

2. Balinger KJ, Chu Lam MT, Hon HH, Stawicki SP, Anasti JN. Amniotic fluid embolism: despite progress, challenges remain. Curr Opin Obstet Gynecol. 2015 Dec;27(6):398405.

3. Conde-Agudelo A, Romero R. Amniotic fluid embolism: an evidence-based review. Am J Obstet Gynecol. 2009 Nov;201(5):445. e1-445.e13.

4. Girendra Sadera, Bharathram Vasudevan. Amniotic Fluid Embolism. Journal of Obstetric Anaesthesia and Critical Care / JanJun 2015 / Vol 5:3-8.

5. Anderson JA, Laloë P, Tuffnell DJ. Amniotic fluid embolism (anaphylactoid syndrome of pregnancy). In: Clark V, Van de Velde $\mathrm{M}$, Fernando R, editors. Oxford textbook of obstetric anaesthesia. S.1.: Oxford Univ Press; 2016. 
6. Tamura N, Farhana M, Oda $\mathrm{T}$, Itoh $\mathrm{H}$, Kanayama N. Amniotic fluid embolism: Pathophysiology from the perspective of pathology: The pathology of AFE. J Obstet Gynaecol Res. 2017 Apr;43(4):627-32.

7. Clark SL. New concepts of amniotic fluid embolism: a review. Obstet Gynecol Surv. 1990 Jun;45(6):360-8.

8. Hankins GD, Snyder RR, Clark SL, Schwartz L, Patterson WR, Butzin CA. Acute hemodynamic and respiratory effects of amniotic fluid embolism in the pregnant goat model. Am J Obstet Gynecol. 1993 Apr;168(4):1113-1129; discussion 11291130.

9. Gist RS, Stafford IP, Leibowitz AB, Beilin Y. Amniotic Fluid Embolism: Anesth Analg. 2009 May;108(5):1599-602.

10. Hacein-Bey L, Varelas PN, Ulmer JL, Mark LP, Raghavan K, Provenzale JM. Imaging of Cerebrovascular Disease in Pregnancy and the Puerperium. Am J Roentgenol. 2016 Jan;206(1):26-38.

11. Sultan P, Seligman K, Carvalho B. Amniotic fluid embolism: update and review. Curr Opin Anaesthesiol. 2016 Jun;29(3):288-96.

12. West M. Amniotic fluid embolism: a historical perspective in diagnosis and management. BJOG Int J Obstet Gynaecol.
2016 Jan;123(1):110.

13. Kobayashi H. Comparison of the Different Definition Criteria for the Diagnosis of Amniotic Fluid Embolism. J Clin Diagn Res [Internet]. 2017 [cited 2017 Oct 23]; Available from: http://jcdr.net/article fulltext.asp?issn=0973-709x\&year $=2017$ $\&$ volume $=11 \&$ issue $=7 \&$ page $=Q C 18 \&$ is $\mathrm{sn}=0973-709 \mathrm{x} \& \mathrm{id}=10283$.

14. Pacheco LD, Saade G, Hankins GDV, Clark SL. Amniotic fluid embolism: diagnosis and management. Am J Obstet Gynecol. 2016 Aug;215(2):B16-24.

15. Unal E, Balci S, Atceken Z, Akpinar E, Ariyurek OM. Nonthrombotic pulmonary artery embolism: imaging findings and review of the literature. Am J Roentgenol. 2017 Mar;208(3):505-16.

16. Plowman RS, Javidan-Nejad C, Raptis CA, Katz DS, Mellnick VM, Bhalla S, et al. Imaging of pregnancy-related vascular complications. RadioGraphics. 2017 Jul;37(4):1270-89.

17. Toledo P, Malinow AM. Embolic Disorders. In: Chestnut DH, Wong CA, Tsen LC, Ngan Kee WD, Beilin Y, Mhyre JM, et al., editors. Chestnut's obstetric anesthesia: principles and practice. Philadelphia, PA: Elsevier/ Saunders; 2014. 